XII Międzynarodowa Konferencja - Electromachining 2015

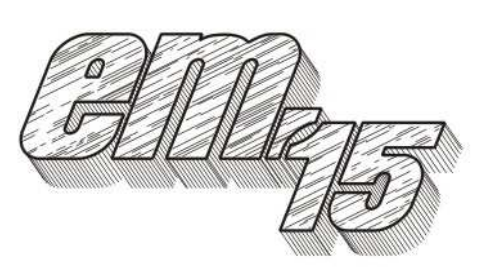

UNIWERSYTET TECHNOLOGICZNO-PRZYRODNICZY

Wydział Inżynierii Mechanicznej, Zakład Inżynierii Produkcji

STOWARZYSZENIE INŻYNIERÓW I TECHNIKÓW

MECHANIKÓW POLSKICH - Koło Uczelniane UTP

85-789 Bydgoszcz, ul. Kaliskiego 7

tel. (0 52) 340-87-47, fax. (0 52) 340-82-45,

e-mail: tomasz.paczkowski@utp.edu.pl

\title{
Improvement of fixed joints quality by integrated technologies of electroerosive alloying
}

\author{
Poprawa jakości stawów za pomocą zintegrowanych technologil stopowanla \\ elektroerozyjnego
}

\author{
VYACHESLAV TARELNYK ${ }^{1}$ \\ BOGDAN ANTOSZEWSKI ${ }^{2}$ \\ IEVGEN KONOPLIANCHENKO ${ }^{3}$ \\ VASYL MARTSYNKOVSKYI ${ }^{4}$
}

In the paper considered questions provide the required quality of mating parts of fixed joints thanks to improving the electroerosive alloying technology and its purposeful combination with other technologies that will considerably increase tightness of fixed joints, as well as their reliability and durability.

KEY WORDS: fixed joint, quality, electro-erosive alloying, polymer, repair, durability

W artykule rozważono zagadnienie zapewnienia wymaganej jakości wspótpracujacych elementów stawów poprzez poprawe technologii stopowania elektroerozyjnego $i$ polaczenie tej operacji z innymi technologiami, które znacznie zwiększają szczelność stawów, a także ich niezawodność i trwalość.

\section{SŁOWA KLUCZOWE: staw (anatomiczny), jakość,} stopowanie elektroerozyjne, polimer, naprawa,

\section{Problem definition in outline}

To provide reliable performance of any machine it should be assembled properly so that all its parts perform their functions, the parts are joined together forming movable or fixed joints.

A press-fit connection or a joint with guaranteed tight is one of the most popular junctions in mechanisms and

\footnotetext{
${ }^{1}$ D.Sc., Professor Vyacheslav B. Tarelnyk (tarelnik@i.ua)

${ }^{2}$ Prof. dr hab. inż. Bogdan Antoszewski (ktrba@tu.kielce.pl)

${ }^{3} \mathrm{Ph}$.D, Assist. Prof. levgen V. Konoplianchenko (konopl_e@i.ua)

${ }^{4}$ Ph.D, Assist. Prof. Vasyl S. Martsynkovskyi (mcb@triz.sumy.ua)
}

machines. Such joints are widely used in machine building for manufacturing turbine rotors, compressors and pumps, shafts with toothed gear wheels, axles and shafts for agricultural machines etc.

Joint strength faults, fretting fatigue and fatigue failures are the most typical fault cases for press-fit and press-key connections. Therefore, improvement of efficiency of these joints is one of the most important tasks to ensure reliability and durability of machine parts.

\section{Analysis of recent researches and publications}

It is possible to assemble fixed surfaces by pressing-in shaft into hole, when part with hole is heated, or when shaft is cooled [13].

Tight junction (with interference fit) of machine parts is carried out thanks to their pre-strain. Tight junction is usually used to join the parts with cylindrical and less often conical contact surfaces. Such junction (as structural assembly) is defined as a joint, wherein load from one part to the other one is transferred due to frictional forces (traction) on the contact surfaces, where frictional forces are generated due to elastic energy. Consequently, the joint has a non-rigid fixation of parts in the axial and circumferential directions.

The advantages of such joints according to $[4,11]$ are the following: possibility of implementation of the joints for very heavy loads and their good perception of shocks; cylindrical and conical joints are relatively cheap and easy to implement; they provide good alignment of mating parts and they do not require any special fasteners. 
The disadvantages of such joints are the following: relative inconvenience of assembling and disassembling (especially inside a one-piece housing); possibility of fit loosening and damage of mounting surfaces when disassembling; large traction scattering due to scattering of actual interference sizes within tolerances and friction coefficients; high concentration of stress; their tendency to contact corrosion due to inevitable axial microdisplacements of points of the parts near the contact edges and, consequently, the reduced efficiency of the joints under variable loads; no rigid fixation of the parts; complications for nondestructive inspection.

It is required that joints should have proper rigidity, since they have to meet requirements for precision under load.

Depending upon possibility of disassembling we can categorize detachable and permanent joints. Detachable joints allow convenient disassembling of machine parts without damage of joined elements. Permanent joints can be disassembled only after their partial or complete destruction. Although tight junctions are conventionally classified as permanent ones, cylindrical joints allow disassembly (pressing-out) and assembly (pressing-in) of the parts [3].

As a rule fixed joints are rather often used to fit gear wheels and impellers, half-couplings, bearing disks, pulleys, star wheels, ball bearings and rolling bearings etc. on shafts and axles.

We emphasize that additionally to the ensuring of joint strength for vessel and piping elements that contain liquids or gases, it is often needed to provide their tightness (leakproofness). For this purpose the contacting surfaces of mechanical joints should be compressed with pressure much higher than ambient pressure.

When assembling the fixed joints, conjugated surfaces of the parts are subjected to plastic deformation, thus it is advisable for solid metal parts to have a softer surface layer.

Modern technology offers a lot of ways to alter the parts surface quality. The electroerosive alloying (EEA) method is one of the most promising technologies.

Characteristic features of the EEA method are the following: any conductive material may be used as an anode (alloying electrode); anode material can form an incrementally deposited coating layer on the cathode surface (alloyed surface); and in this case there is no boundary between the deposited material and the substrate metal, moreover anode elements diffuse into the cathode; it is possible to alloy preset areas, without protecting the rest surface of the part. Metal surface hardness can be altered be means of EEA: the surface hardness can be increased by depositing material with higher hardness onto the substrate surface or by diffusion transfer of required chemical elements from the environment or from the anode material into the surface layer; or the surface hardness can be decreased by depositing softer materials onto the substrate surface. We can also increase the surface hardness when dealing with unhardened but hardenable material by applying higher current or longer pulses, which heat up the metal a bit deeper than total thickness of the applied and diffusion layers [2, 12].

\section{Formulation of the article object (problem statement)}

Thus the object of the research was to provide the required quality of mating parts of fixed joints thanks to improving the EEA technology and its purposeful combination with other technologies that will considerably increase tightness of fixed joints, as well as their reliability and durability.

\section{Description of basic material of the research}

The results of the joint research carried out by the researches of department of Technical Service of Sumy National Agrarian University and "TRIZ" Ltd enterprise (Engineering Problems Realization Company), Sumy, are stated below.

There are almost no references on application of EEA for surface layer hardness reduction of the parts, although technologists quite often face such a task. For example, in order to increase tightness of the joint when assembling the heat-treated parts, one or both mating surfaces should be softer. The proper softness can be achieved by reducing microhardness of the surface layer in any preset area, not altering hardness of the entire part.

Patent [9] suggests that the objective can be achieved, when a surface layer is formed on the mating pretreated surface of the part with a graphite electrode by applying EEA method.

When steel cathodes are EEA-treated with the graphite electrode, a "white" layer is formed on the cathode surfaces, and this "white" layer usually cannot be etched with reagents used for the substrate material. Microhardness of the "white" layer is considerably higher than hardness of the substrate metal. Under the "white" layer there is a conversion zone, i.e. a sublayer, where heat affection with pulse discharges and diffusive mutual penetration of anode and cathode elements took place. The sublayer is usually a tempering zone, and its size is conditioned by parameters of the pulsed discharge. The higher is the latter, the bigger is the zone. Hardness of the tempering zone is lower than hardness of the substrate metal. Zone of heat affection may run up to $400 \mu \mathrm{m}$ when its surface is treated with the graphite electrode using long duration high current pulses up to $9,10^{-4} \mathrm{~s}$ and at energy of $0,4-4,0 \mathrm{~J}$.

When EEA with the graphite electrode the surface roughness of the treated material is least altered, $100 \%$ uniformity of the alloyed surface is achieved, the metal electrode that is being used leaves no coating, the electrode does not stick during the process of EEA and, finally, a cheaper electrode material is used.

Depth of higher and lower hardness zones is obtained experimentally for each element material and for each EEA modes. Zone with higher hardness is removed by any known method, for example, by grinding.

When heat-treated parts from nonferrous alloys, e.g. beryllium bronze, are EEA-treated using the graphite electrode on the device "UILV-8" model at discharge energy $W_{p}=0,42 \mathrm{~J}$ (Fig. 1), a tempering zone is formed directly on the surface; depth of the tempering zone depends upon the mode of alloying, just as in the case of alloying of steel parts. The more is discharge energy and the longer is alloying time, the deeper is the layer with lower hardness.

Microstructures analysis (see Fig. 1) and data of Table 1 show that increase of alloying time from 1 to $4 \mathrm{~min} / \mathrm{cm}^{2}$ results in increase of weakened layer depth from $25 \mu \mathrm{m}$ to $120 \mu \mathrm{m}$. At the same time microhardness increases from $1450 \mathrm{MPa}$ to $2290 \mathrm{MPa}$. 


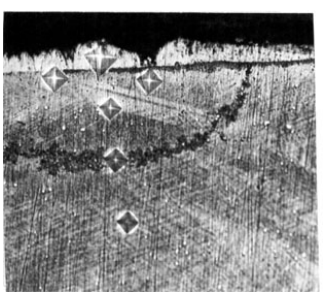

a

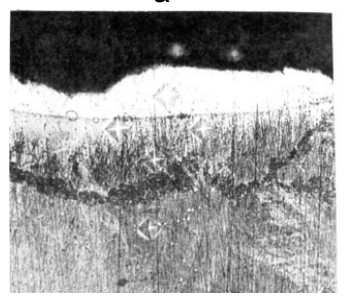

C

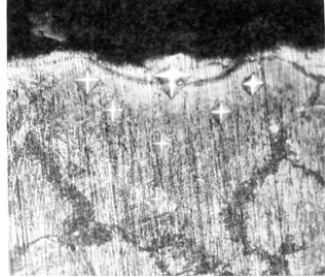

b

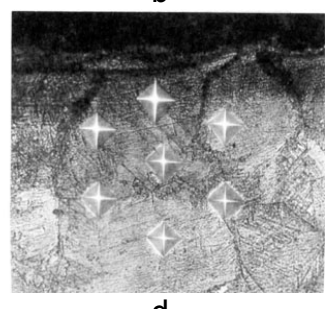

d
Fig. 1. Microstructure of the surface layer of beryllium bronze CuBe2Ni(Co) BrB2 (GOST) after EEA-treatment using carbon within: $a-1 \min , b-2 \min , c-3 \min , d-4 \min , x 400$

Table1. Microhardness distribution and depth of weakened surface layer of beryllium bronze $\mathrm{CuBe} 2 \mathrm{Ni}(\mathrm{Co}) \mathrm{BrB} 2$

(GOST)

\begin{tabular}{|c|c|c|}
\hline $\begin{array}{c}\text { EEA } \\
\text { capacity, } \\
\mathrm{min} / \mathrm{cm}^{2}\end{array}$ & $\begin{array}{c}\text { Layer } \\
\text { depth, } \\
\mu \mathrm{m}\end{array}$ & $\begin{array}{c}\text { Microhardness distribution in } \\
\text { proportion to deepening from the } \\
\text { surface, MPa }\end{array}$ \\
\hline 1.0 & 25 & $1450,1950,3120,3700$ \\
\hline 2.0 & 30 & $1400,2600,2800,3700$ \\
\hline 3.0 & 50 & $1840,1950,2200,3700$ \\
\hline 4.0 & 120 & $2290,2500,2600,3700$ \\
\hline
\end{tabular}

Thus, the necessary time for alloying with carbon depends upon the required depth and desired microhardness of the surface layer.

Quality of mating parts of fixed joints can be improved by applying special coatings that alter structure of mating surfaces of the parts.

Thus, patent [8] suggests the following method of treatment of mating surfaces of steel and/or cast iron parts.

The method is detailed below. Nickel coating is applied on the mating surface of steel and/or cast iron parts (irrespective of their heat treatment) by means of EEA method. At that pulse discharges at energy of $0,01-0,63 \mathrm{~J}$ are used to form a surface layer, microhardness of which is lower than the part substrate microhardness.

Thereafter, bands of 4-6 mm width are applied with the same interval on nickel surface layer by means of the above mentioned method and in the same modes using WCo (Tungsten-Cobalt alloy) or WTi (Tungsten Titanium alloy) hard alloy group electrodes (areas 1, Fig. 2).

In the surface layer formed by the method described above, strength, safety and durability of fixed joint is ensured by the coating, consisting of the bands, formed by successive application of nickel and hard alloy (bands 1 , Fig. 2). In the described case, the coating with solid, durable surface layer having high $(0,3-0,7)$ friction coefficient is formed. Under this surface layer there is the layer, microhardness of which is lower than the substrate microhardness. When assembling the hard surface layer is pressed into the soft lower layer, however tightness of the joint is not ensured here.
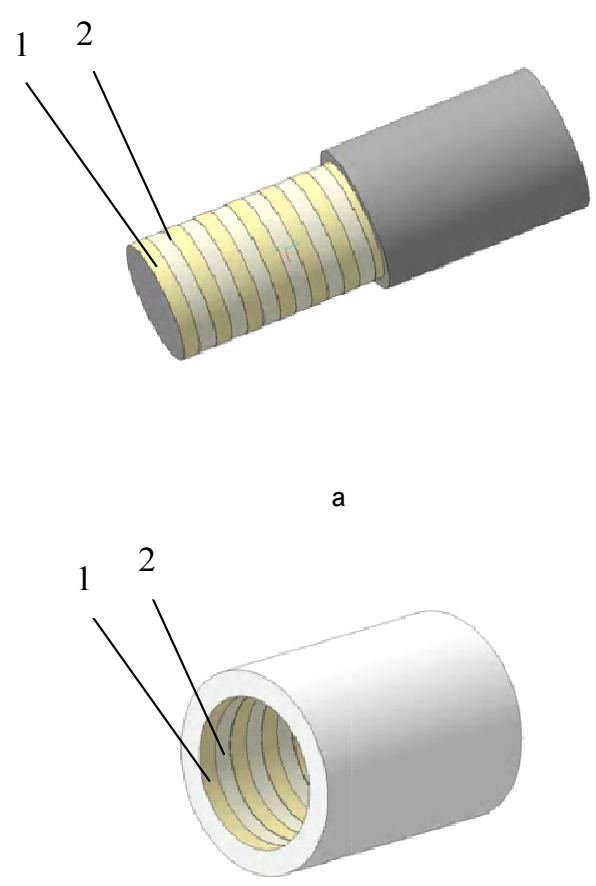

b

Fig. 2. Shaft (a) and bushing (b) surfaces with the bands of electroerosive coatings: 1 - with hard alloy of WCo or WTi group; 2 - with nickel

Surface bands of nickel coating ensure tightness of the fixed joint, as microhardness of nickel bands is lower than microhardness of the substrate (bands 2, Fig. 2)

Description of mating surfaces treating method for parts made of high-test cast iron VCH60 (GOST) is given below.

High-test cast iron VCH60 samples $(10 \times 10 \times 8 \mathrm{~mm})$ were EEA-treated on the device "Elitron 22A" model. Alloying was carried out within 1,5 min using the $6^{\text {th }}$ mode $(\mathrm{Wp}=0,63 \mathrm{~J})$.

Nickel (Ni) and hard alloy WCo8 were used as electrode materials. Moreover, composite electroerosive coatings consisting of nickel and WCo8 were applied.

Slices of samples after EEA-treatment were used for studying the structure and microhardness of the surface layer. The obtained slices were examined under the optical microscope "Neophot-2" and a scanning electron microscope with analyzer "REM - 106 I" of Sumy Production Association "Electron", which one was used for evaluation of the layer quality, its uniformity, thickness and structure of sublayer zones - diffusion zone and heat affected zone. Simultaneously a durometric analysis was carried out to investigate the microhardness distribution in the surface layer and throughout the slice depth starting from the surface. The microhardness was measured on the microhardness tester PMT- 3 by impressing of a diamond pyramid under the load of $0,5 \mathrm{~N}$.

The metallographic examinaton proved that the formed coatings consist of two layers. The "white" layer is on the top. Below there is a darker conversion layer. Sometimes there can appear the third layer, i.e. the heat-affected zone. 
When VCH60 sample undergoes electroerosive alloying with nickel, the surface layer is formed with thickness up to $70 \mu \mathrm{m}$ and microhardness equal to $2200-2760 \mathrm{MPa}$. Below there is a conversion layer that is formed due to joint action of diffusion and heat. Microhardness of this layer is 4290 $5260 \mathrm{MPa}$.

The results of microhardness distribution throughout the layer depth of high-test cast iron and steel 45 (GOST) samples are shown in Table 2.

Table 2. Characteristics of electroerosive coatings for hightest cast iron and steel 45

\begin{tabular}{|c|c|c|c|c|c|}
\hline \multirow[b]{2}{*}{ 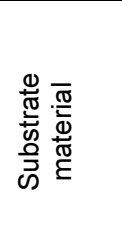 } & \multirow[b]{2}{*}{ 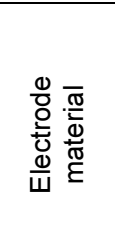 } & \multicolumn{2}{|c|}{ Thickness, $\mu \mathrm{m}$} & \multicolumn{2}{|c|}{$\begin{array}{c}\text { Microhardness, } \\
\text { MPa }\end{array}$} \\
\hline & & 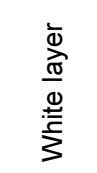 & 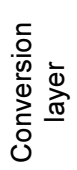 & 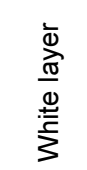 & 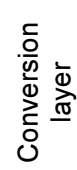 \\
\hline VCH60* & $\mathrm{Ni}$ & $\begin{array}{c}\text { up to } \\
70\end{array}$ & 10 & $\begin{array}{l}2200- \\
2760\end{array}$ & $\begin{array}{r}4290 \\
5260\end{array}$ \\
\hline VCH60 & WCo8 & $25-30$ & 15 & $\begin{array}{l}5790- \\
10300\end{array}$ & 4900 \\
\hline VCH60 & $\begin{array}{c}\mathrm{Ni}+ \\
\text { WCo8 }\end{array}$ & 20 & $\begin{array}{l}65- \\
85 \\
\end{array}$ & 11830 & $\begin{array}{r}2200 \\
4580 \\
\end{array}$ \\
\hline Steel $45^{\pi /}$ & $\mathrm{Ni}$ & 25 & 10 & 2000 & 2500 \\
\hline Steel 45 & WCo8 & 20 & 10 & 11000 & 3500 \\
\hline Steel 45 & Steel 45 & 15 & $\begin{array}{l}60- \\
70\end{array}$ & 10000 & $\begin{array}{l}2000- \\
5750\end{array}$ \\
\hline
\end{tabular}

Press-fit connections have a specific feature: their parts are at stress state even before workloads are applied to them. The stress state is caused by interference at the mounting surfaces. Summation of stresses due to work and interference may cause their significant concentration in certain mating areas. Concentration of stress and fretting fatigue results in reduction of fatigue limit of the shaft in its wheel seat under the hub end. Influence of these factors can be reduced by lowering the total rigidity of the hub, especially at its ends, e.g. by pressing-in rings of softer materials into the rectangular grooves of bore diameter at the hub ends (Fig. 3) [1].

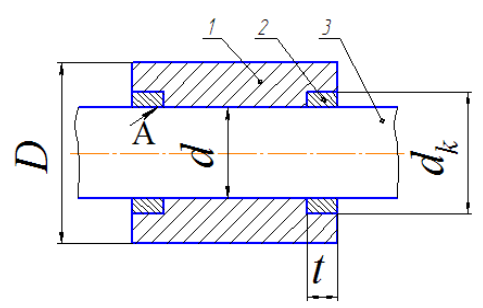

Fig. 3. Press-fit connection with the insertion rings: $1-$ hub; 2 - insertion ring; 3 - shaft

Ring height should be selected taking into consideration the tightness in the joint and the transmitted load, which determines relative slip amplitude of the hub 1 and the shaft 3 . The softer rings 2 in zones of maximum contact pressure smooth stress peaks and reduce damage rate during fretting corrosion.

The test carried out on the 40X (GOST) steel samples with diameter $\mathrm{d}=20 \mathrm{~mm}$ and hubs with diameter $\mathrm{D}=37$ $\mathrm{mm}$ and length equal to $90 \mathrm{~mm}$, having rings of M2 (GOST) tough-pitch copper, showed, that their fatigue limit has increased twice (from $150 \mathrm{MPa}$ to $300 \mathrm{MPa}$ ) at pure bending with $50 \mathrm{~Hz}$ frequency.
To improve shaft fatigue strength of press-fit shaft-hub joints it is recommended in $[5,6]$ to deposit $5-10 \mathrm{~mm}$ wide bands of softer material onto the inner surface of the hub close to its face plane using EEA method (Fig. 4). Copper and tin bronze can be suggested as materials for electrodes that allow obtaining up to $100 \%$ coatings integrity on the steel surface.

In the present embodiment there appears possibility to use such a constructive method as rounding off the hub inner face planes that also ensures reduction of the hub rigidity. Moreover, to the advantages of the suggested method one may refer saving of nonferrous metals, as well as simplification of the hub manufacturing technique.
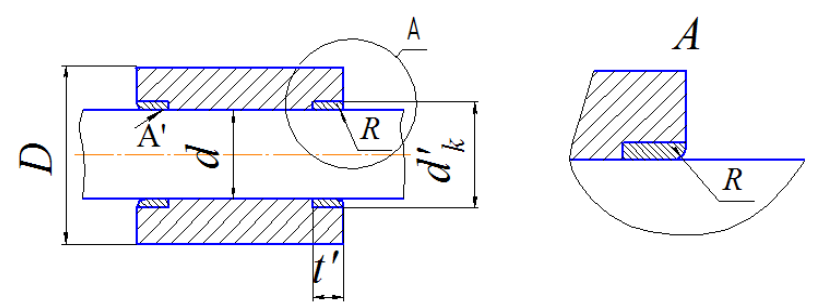

Fig. 4. The hub with copper diffusion layer and rounded-off face planes

It should be noticed that the best coating quality (integrity, roughness, uniformity, etc) is obtained when argon is used as a protective medium.

It is also possible to increase fatigue strength of the shafts as well as reliability and durability of the press-fit connections using electroerosive alloying cementation (EEAC) of the wheel seat of the shaft. Later, as a next step, the cemented layer is coated with soft antifrictional material (e.g. copper or silver) using the abovementioned method and undergoes surface plastic deformation with a ball, a roller or is processed with nonabrasive ultrasonic finishing (NUFM).

The method and results of the research are described below.

EEAC process was carried out automatically on a special device in different modes within discharge energy range $\left(\mathrm{W}_{\mathrm{p}}\right)$ from $0,1 \mathrm{~J}$ to $6,8 \mathrm{~J}$.

The special samples were used for the research. The samples were made of $40 \mathrm{X}$ steel in the shape of a coil consisting of two $50 \mathrm{~mm}$ in diameter discs, each $10 \mathrm{~mm}$ wide, connected to each other with a spacer $15 \mathrm{~mm}$ in diameter and having two process sections of the same diameter (Fig. 5). Before being treated with EEAC the surfaces were polished up to $\mathrm{Ra}=0,5 \mu \mathrm{m}$. The samples were fixed in the chuck of the turning machine, then EEAC, alloying with silver and copper and NUFM processing were carried out. The surface roughness was measured with a profilograph-profilometer mod. 201 manufactured by "Kalibr" factory.

Results of the investigation of two series of $40 \mathrm{X}$ steel samples are represented below: 1 - cementation, alloying with silver, NUFM processing; 2 - cementation, alloying with copper, NUFM processing.

The results of the surface roughness measurements are represented in Table 3 and the results of durometric investigations are shown in Figures 6 and 7. 


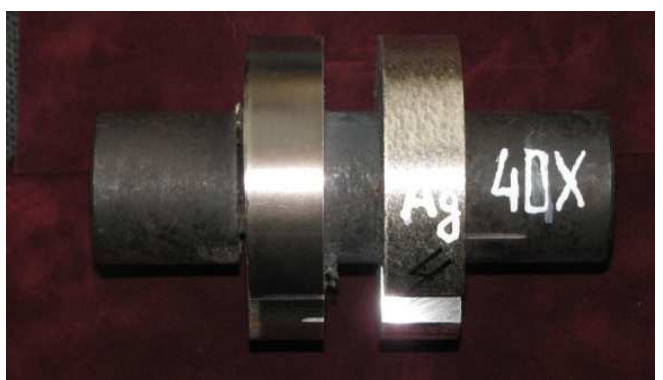

a

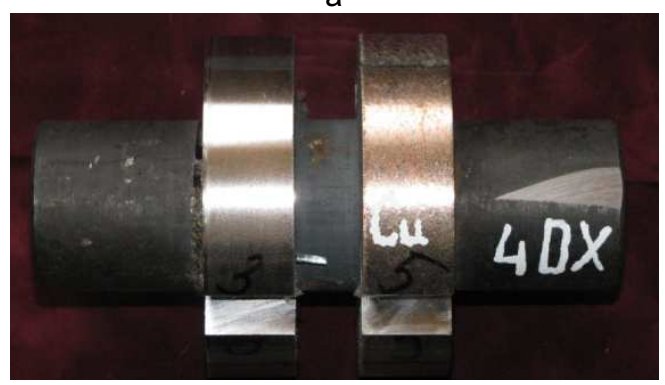

b

Fig. 5. Steel samples for investigation of result of EEAC and EEA: $a-$ with silver and $b$ - with copper.

Table 3. Surface roughness of two series of samples

\begin{tabular}{|c|c|c|c|c|c|c|c|c|}
\hline \multicolumn{9}{|c|}{ EEA with silver } \\
\hline \multicolumn{7}{|c|}{ Surface roughness value in certain points, $\mu \mathrm{m}$} & \multirow{2}{*}{\multicolumn{2}{|c|}{$\begin{array}{c}\text { Roughness } \\
\text { mean value, } \\
\mu \mathrm{m}\end{array}$}} \\
\hline \multicolumn{7}{|c|}{$\mathrm{Ra}$} & & \\
\hline 0,59 & 0,86 & 1,27 & 0,47 & 1,33 & 0,76 & 0,59 & & \\
\hline \multicolumn{7}{|c|}{$\mathrm{Rz}$} & $\mathrm{R}_{\mathrm{a}}$ & $\mathrm{R}_{\mathrm{z}}$ \\
\hline 1,68 & 2,44 & 3,59 & 1,33 & 3,76 & 2,14 & 1,68 & 0,88 & 2,49 \\
\hline \multicolumn{9}{|c|}{ EEA with copper } \\
\hline \multicolumn{7}{|c|}{ Surface roughness value in certain points, $\mu \mathrm{m}$} & \multirow{2}{*}{\multicolumn{2}{|c|}{$\begin{array}{c}\text { Roughness } \\
\text { mean value, } \\
\mu \mathrm{m}\end{array}$}} \\
\hline \multicolumn{7}{|c|}{$\mathrm{Ra}$} & & \\
\hline 0,55 & 0,65 & 0,91 & 0,62 & 0,87 & 0,71 & 0,51 & & \\
\hline \multicolumn{7}{|c|}{ Rz } & $\mathrm{R}_{\mathrm{a}}$ & $\mathrm{R}_{\mathrm{z}}$ \\
\hline 3,05 & 2,40 & 2,35 & 2,64 & 2,48 & 3,01 & 3,25 & 0,80 & 3,19 \\
\hline
\end{tabular}

Fig. 6 shows the microslice and microhardness distribution in the sample of series 1 . As can be seen from the Figure, on the surface of the sample there is a layer up to $35 \mu \mathrm{m}$ deep with hardness of about $80-90 \mathrm{HV}$, which hardness is lower than the substrate microhardness (220 $H V$ ). The microhardness gradually increases with deepening and at the depth of ca. $60 \mu \mathrm{m}$ it reaches its maximum value of $470 \mathrm{HV}$, and then it gradually decreases again and at a depth of $100 \mu \mathrm{m}$ it corresponds to the substrate microhardness.

It should be noted that the sample diameter increased by $0,04 \mathrm{~mm}$ after EEA with silver and decreased by $0,02 \mathrm{~mm}$ after NUFM processing.

Fig. 7 shows the microslice and microhardness distribution in the sample of series 2 . As can be seen from the Figure, on the surface of the sample there is a layer up to $40 \mu \mathrm{m}$ deep with hardness of about $140-170 \mathrm{HV}$, which hardness is lower than the substrate microhardness (220 HV). The microhardness gradually increases with deepening and at the depth of ca. $75 \mu \mathrm{m}$ it reaches its maximum value of $510 \mathrm{HV}$, and then it gradually decreases again and at a depth of $120 \mu \mathrm{m}$ it corresponds to the substrate microhardness.

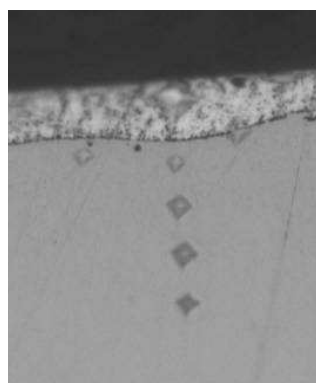

a

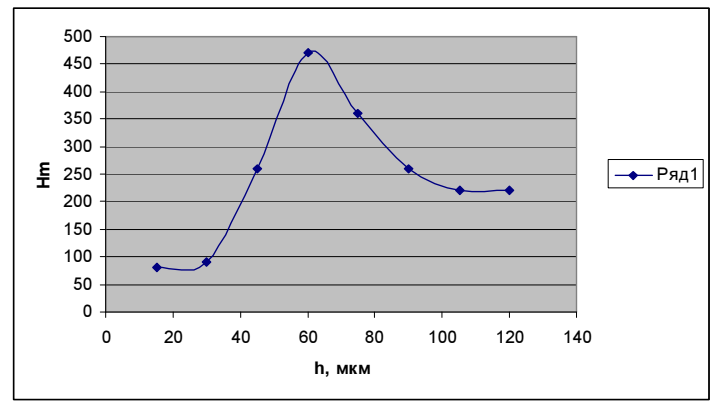

b

Fig. 6 - Microslice (a) and microhardness distribution in the 40X steel surface layer after EEAC, EEA with silver and NUFM processing (b).

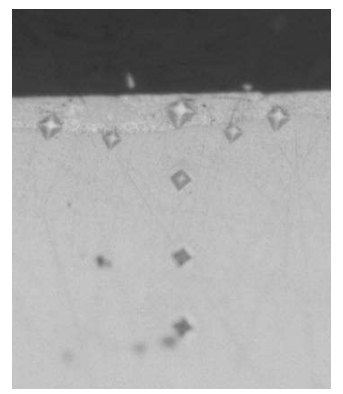

a

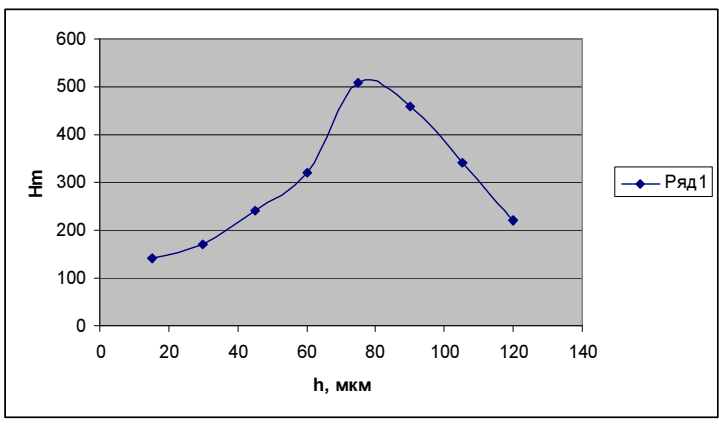

b

Fig. 7. Microslice (a) and microhardness distribution in the 40X steel surface layer after EEAC, EEA with copper and NUFM processing (b).

It should be noticed that the thickness of the applied soft antifrictional material layer can be controlled through the EEA mode, application method and the electrode material. Transition radius (fillet) from the shaft thickened area to the normal diameter can be formed by reducing discharge energy (when less electrode material is transferred onto the substrate), as well as by increasing the burnishing force.

When assembling the hub and the shaft, soft antifrictional material, which lies between the hard hub surface and the hard EEAC-generated shaft sublayer, undergoes deforming 
and penetrates into all holes eliminating asperities and imperfections of the surfaces of the mating parts. As a result the area of the mating surfaces of the hub and the shaft increases considerably (up to $100 \%$ ), thus causing increase of the joint tightness as well as increase of the friction force at moving and torsional loads, which finally increases reliability and durability of the joint.

Moreover, the advantages of the suggested method include saving of metal when manufacturing shafts with enlarged diameter, as well as simplification of manufacturing technique for such shafts.

Since operational faults of press-fit connections take place mostly because of tightness loosening (wearing of the contact surfaces of the mating parts due to fretting corrosion or damages as a result of disassembling), it is essential to find the most efficient recovery method for repairing such joints.

Currently the new technologies of equipment repairing with the help of polymer compounds are used more extensively for maintenance works. These compounds characteristics are the following [7]: they have good adhesion to metal; their strain characteristics are close to metal; their properties alter not significantly with temperature changes; their shrinkage during hardening is minimal; they feature good resistance to the influence of external factors, etc.

It should be noticed that to obtain proper adhesion of plastic to the surface of a workpiece, the surface of the workpiece should be properly roughened.

The consideration that the characteristic features of the EEA method and the fact that different alloying modes provide a good possibility to alter the surface roughness (Rz) over a wide range from $1 \mu \mathrm{m}$ to $200 \mu \mathrm{m}$ gives us a good opportunity to use integrated technology of EEA and further application of polymer materials to improve significantly quality of fixed joints, especially when repairing [10]. Even when viewing them on their own, these technologies in no way belittle the advantages of each other, but on the contrary they complement each other and eliminate disadvantages inherent in each one used individually. By means of the EEA method it is possible to form either the hardened surface layer or the coating of hard durable material. Further they can be coated with polymer material that penetrates into voids between surface asperities and provides $100 \%$ uniformity and much lower roughness than roughness of the surface or coating without additional treatment, as well as higher hardness and durability than application of only polymer compounds can provide.

\section{Conclusions}

Quality of the fixed joints can be improved by means of:

1. Reducing the surface hardness of heat-treated steel and non-ferrous alloys using EEA with carbon (graphite electrode).

2. Coating the surface of steel and/or cast iron parts with nickel using EEA and with bands using hard alloy electrodes of WCo and WTi groups.

3. Improvement of shaft fatigue strength of press-fit shafthub joints by deposition of $5-10 \mathrm{~mm}$ wide bands of softer material onto the inner surface of the hub close to its face plane using EEA method. Copper and tin bronze can be recommended as materials for electrodes, since these materials allow obtaining up to $100 \%$ coatings uniformity on the steel surface.
4. Improvement of shaft fatigue strength using EEAC for its wheel seat surface and subsequent applying of soft antifrictional material, for example, copper or silver, using the EEA method, followed by NUFM processing.

5. Using integrated technology of the EEA method and further application of polymer materials during repairing.

\section{REFERENCES}

1. Balatskyi L. T., Strength of press-fit connections. K. Tekhnika, 1982.

2. Gitlevich A.Ye., Mikhaylov V.V., Parkanskyi N.Ya., Revutskyi V.M., Electroerosive alloying of metal surfaces. Shtintsa, Kishinev 1985

3. Guzenkov P.G., Machine parts. M.: Vysshaya shkola, 1982.

4. Iosilevich G.B., Machine parts: A textbook for students of machinebuilding specialties of higher educational establishments. M.: Mashynostroeniye, 1988.

5. Ishchenko A.A., Background technology for renovation of industrial equipment using polymeric materials. PGTU Mariupol:, 2007.

6. Martsynkovskyi V.S., Tarelnyk V.B., Bratyshchak M. P., Manufacturing method of a fixed shaft-hub joint of steel parts (embodiments). Pat. 2501986. Russian Federation. IPC B23H 9/00 / Published. 20.12.13, Off. J. No 35.

7. Martsynkovskyi V.S., Tarelnyk V.B., Bratyshchak M.P., Manufacturing method of a fixed shaft-hub joint of steel parts (embodiments). Pat. 103098. Ukraine. IPC B23H 9/00/ Published 10.09.13, Off. J. No 3 .

8. Martsynkovskyi V. S., Tarelnyk V.B., Konoplyanchenko Ye. V.,, Oleynik I. A., Method for treatment of connecting surfaces of steel and/or cast iron components. Pat. 2410212. Russian Federation. IPC B23H 9/00/.; Published 27.01.11, Off. J. No 3.

9. Martsynkovskyi V.S., Tarelnyk V.B., Method for treatment of connecting surfaces of components (embodiments): Pat. 66105. Ukraine. IPC B23H 1/00 / Published 10.04.08, Off. J. No 7.

10. Martsynkovskyi V.S., Tarelnyk V.B., Pavlov O.G., Ishchenko A.O., Method for recovery of worn-out surfaces of metal parts (embodiments): Pat. 104664. Ukraine. IPC B23H 5/00 /:; Published 25.02.2014, Off. J. No 4.

11. Reshetov D.N., Machine parts: A textbook for students of machinebuilding and mechanical specialties of higher educational establishments. M.: Mashynostroeniye, 1989.

12. Verkhoturov A.D., Mukha I.M., Technology of electroerosive alloying of metal surfaces. - K. Tekhnika, 1982.

13.Zuyev A.A., Gurevich D.F., Technology of agricultural machine building. M., Kolos, 1989. 